Abstracta Iranica Abstracta Iranica

Revue bibliographique pour le domaine irano-aryen

Volume 40-41 | 2019

Comptes rendus des publications de 2017-2018

\title{
Samuel N. C. Lieu, Erica Hunter, Enrico Morano, Nils Arne Pedersen (eds.). Manichaeism East and West
}

\section{Christiane Reck}

\section{(2) OpenEdition \\ 1 Journals}

\section{Electronic version}

URL: http://journals.openedition.org/abstractairanica/48973

DOI: 10.4000/abstractairanica.48973

ISBN: 1961-960X

ISSN: 1961-960X

Publisher:

CNRS (UMR 7528 Mondes iraniens et indiens), Éditions de l'IFRI

Electronic reference

Christiane Reck, "Samuel N. C. Lieu, Erica Hunter, Enrico Morano, Nils Arne Pedersen (eds.).

Manichaeism East and West", Abstracta Iranica [Online], Volume 40-41 | 2019, document 1, Online since 30 October 2019, connection on 17 April 2021. URL: http://journals.openedition.org/abstractairanica/ 48973 ; DOI: https://doi.org/10.4000/abstractairanica.48973

This text was automatically generated on 17 April 2021.

Tous droits réservés 


\title{
Samuel N. C. Lieu, Erica Hunter, Enrico Morano, Nils Arne Pedersen (eds.). Manichaeism East and West
}

\author{
Christiane Reck
}

\section{REFERENCES}

Samuel N. C. Lieu, Erica Hunter, Enrico Morano, Nils Arne Pedersen (eds.). Manichaeism East and West. Turnhout: Brepols, 2017, XI+260p., 2 b/w ill. +28 colour ill., 2 b/w tables (Corpus Fontium Manichaeorum: Analecta Manichaica 1). ISBN 978-2-503-57457-8

1 This volume opens a new sub-series, Analecta Manichaica, of the very successful series Corpus Fontium Manichaeorum. This sub-series shall be used not only for publishing the proceedings of the international conferences of the International Association of Manichaean Studies (IAMS), but also serve as a peer-reviewed occasional journal of the IAMS.

2 This first volume contains the proceedings of the $8^{\text {th }}$ International Conference of the IAMS held at the School of Oriental and African Studies (SOAS) in London, $9^{\text {th }}-13^{\text {th }}$ September 2013. The 21 contributions published here give a representative overview of recent research and trends in Manichaeism in the world. The Presidential Address by Samuel N.C. Lieu "Manichaeism East and West" underlines the aim of the conferences to bring together the widespread research on the diverse sources of Manichaeism. One major topics concerns comparisons of Syriac, Greek and Coptic sources with each other and with still others (Iain Gardner and Leyla Rasouli-Narimani "Patīg and Pattikios in the Manichaean sources", Nils Arne Pedersen "Observations on the Book of the Giants from Coptic and Syriac Sources", Flavia Ruani "John of Dara on Mani: Manichaean Interpretations of Genesis 2:17 in Syriac", Christos Theodorou "Heavenly Garment and Christology in Western Manichaean Sources", Satoshi Toda "Some Observations on Greek Words in Coptic Manichaean Texts"); other articles study specific aspects 
(Fernando Bermejo Rubio "Violence and Myth: Some reflections on an aspect of the Manichaean Protology and Eschatology", Jean-Daniel Dubois "The Coptic Manichaean Psalm to Jesus, No. 245", Majella Franzmann "The Elect Cosmic Body and Manichaeism as an exclusive religion", Matthew Goff "Wild Cannibals or Repentant Sinners? The value of the Manichaean Book of Giants for understanding the Qumran Book of Giants", Rea Matsangou "Real and Imagined Manichaeans in Greek Patristic anti-Manichaica, $4^{\text {th }}-6^{\text {th }}$ centuries"). Two articles discuss the reception of Manichaeism in later sources up to the present (Dilâ Baran Tekin "Mani and his teachings according to Islamic sources: An introductory study" and Jonathan Smith "Persia, Sun, Fire, Execution, and Mercy: Jean Baudrillard's postmodern reception of Charles Allberry's A Manichean Psalm-Book, Part II (1938)"). Jason BeDuhn and Greg Hodgins ("The date of the Manichaean codices from Medinet Madi and its significance") report on the radiocarbon measurement of material which can now be dated to between the end of the $4^{\text {th }}$ and the beginning of the $5^{\text {th }}$ century AD.

Because of the author's personal interest, the following articles are listed separately. The contributions by Adam Benkato "Incipits and Explicits in Iranian Manichaean texts" and Claudia Leurini "The Messiah in Iranian Manichaean Texts" deal with special problems in the Manichean Middle Iranian text fragments from Turfan in comparison with the Western Manichaean tradition. Iris Colditz ("On the names of 'Donors' in Middle Iranian Manichaean texts") lists and analyzes the character and function of the proper names found at the end of hymns or prose passages. Enrico Morano publishes in "Manichaean Sogdian poems" three poetic Sogdian texts which are unique within the Middle Iranian Manichaean literature. Zsuzsanna Gulásci ("Exploring the relic function of Mani's Seal Stone in the Bibliothèque nationale de France") introduces a rock crystal seal stone kept in the Bibliothèque national de France as Mani's own seal stone showing Mani himself - with an inscription which indicates the person as Mani, the apostle of Jesus Christ - with two other persons and. Gábor Kósa ("Adamas of Light in the Cosmology Painting") contributes to the interpretation of a then recently found Chinese Manichaean Cosmology painting which fits the literary sources in an astonishing way and illustrates them extraordinarily. In the meantime, Yutaka Yoshida and Zsuzsanna Gulácsi have continued the description and interpretation of this painting in books and articles. Yutaka Yoshida ("Middle Iranian Terms in the Xiapu Chinese texts: Four aspects of the Father of Greatness in Parthian") begins to examine the Chinese Manichaean texts most recently discovered in Xiapu, Fujian in respect to their character as transcriptions of Middle Iranian texts in Chinese script and attempts to discover the underlying verses. The project of identification and research on these texts is still going on.

4 The volume is excellently edited with black/white and colour plates. 


\section{AUTHORS}

\section{CHRISTIANE RECK}

Akademie der Wissenschaften Göttingen 